\title{
Abiotic Mimic of Endogenous Tissue Inhibitors of Metalloproteinases: \\ Engineering Synthetic Polymer Nanoparticles for Use as a Broad-Spectrum Metalloproteinase Inhibitor Masahiko Nakamoto†, Di Zhao†, Olivia Rose Benice†, Shih-Hui Lee†, Kenneth J. Shea† \\ $\uparrow$ Department of Chemistry, University of California, Irvine, Irvine, California 92697, USA
}

\section{TABLE OF CONTENTS}

1. MATERIALS AND INSTRUMENTATION

2. MONOMER SYNTHESIS

3. SYNTHESIS AND CHARACTERIZATION OF NANOPARTICLE

4. SVMPS INHIBITION ASSAY

5. DOCKING SIMULATION

6. PULL-DOWN FILTER EXPERIMENT

7. SDS-PAGE VISUALIZATION AND MASS-SPECTROMETRIC ANALYSIS 


\section{MATERIALS AND INSTRUMENTATION}

\section{Materials}

The following materials were obtained from commercial sources. $\mathrm{N}$-isopropylacrylamide (NIPAm), $\mathrm{N}$-phenylacrylamide, 6-aminohexanoic acid, L-Leucine, L-phenylalanine, L-phenylalanine methyl ester, 4-aminobenzamidine, methacryloyl chloride, sodium dodecyl sulfate (SDS), ammonium persulfate (APS), azobisisobutyronitrile (AIBN), Cetyltrimethylammonium bromide (CTAB), Dulbecco's phosphate buffered saline and Crotalus atrox venom and human serum were obtained from Sigma Aldrich. $N, N^{\prime}$-methylenebisacrylamide (BIS) was from Fluka. Acryloyl chloride was obtained from Alfa aesar Inc. All other solvents and chemicals were obtained from Fisher Scientific Inc. or VWR International LLC. Bitis arietans, Bitis gabonica, Echis ocellatus and Echis carinatus venom were obtained from LATOXAN Inc. Precast SDS-PAGE gels (4-15\% Mini-Protean), Tris/Glycine/SDS (10X), Coomassie Brilliant Blue R-250 and molecular weight ladder (Precision plus protein standards) were purchased from Bio-rad Laboratories. NuPAGE ${ }^{\mathrm{TM}}$ LDS Sample Buffer (4X) and NuPAGE ${ }^{\mathrm{TM}}$ Sample Reducing Agent (10X) were purchased from Thermo Fisher Scientific Inc. NIPAm was recrystallized from hexanes and benzene. Water used in polymerization was purified using a Barnstead Nanopure DiamondTM system. 12-14 kDa MWCO cellulose membranes were purchased from Fisher bland, Inc.

\section{Instrumentation}

UV-Vis absorption spectra were measured using a Thermo Scientific 2000c Nanodrop. Hydrodynamic diameter of nanoparticle was determined using a Malvern ZEN3600 dynamic light scattering (DLS) instrument with a disposable sizing cuvette. Lyophilization of polymer samples was performed using a Labconco Freezone 4.5. Mass spectrometry was performed using a $A B$ SCIEX TOF/TOF 5800 System. 


\section{MONOMER SYNTHESIS}

\section{Synthesis of 6-methacrylamidohexanoic acid (MHCA)}<smiles>C=C(C)C(=O)C(C)CCCCC(=O)O</smiles>

6-aminobutyric acid ( $4 \mathrm{~g}, 30.5 \mathrm{mmol}$ ) and potassium hydroxide $(5.1 \mathrm{~g}, 91.5 \mathrm{mmol}, 3 \mathrm{eq}$.) were dissolved in water at $0^{\circ} \mathrm{C}$. Methacryloyl chloride $(4.465 \mathrm{~mL}, 45.7 \mathrm{mmol}, 1.5 \mathrm{eq}$.) was added to the solution dropwise and stirred at $0^{\circ} \mathrm{C}$ for $3 \mathrm{~h}$. $\mathrm{pH}$ of the solution was tuned to 2.0 using $5 \mathrm{~N} \mathrm{HCl}$. The solution was extracted with dichloromethane (DCM) and dried over $\mathrm{MgSO}_{4}$. After evaporation, colorless oil was recrystallized from ethyl acetate, resulting in white solid (Yield: 62\%).

${ }^{1} \mathrm{H}$ NMR $(500 \mathrm{MHz}, \mathrm{DMSO}-d 6): \delta(\mathrm{ppm})=11.99(1 \mathrm{H}, \mathrm{s}), 7.87(1 \mathrm{H}, \mathrm{s}), 5.62(1 \mathrm{H}, \mathrm{s}), 5.29(1 \mathrm{H}, \mathrm{s}), 3.09$ $(2 \mathrm{H}, \mathrm{m}), 2.19(2 \mathrm{H}, \mathrm{t}), 1.84(3 \mathrm{H}, \mathrm{s}), 1.42(4 \mathrm{H}, \mathrm{m}), 1.26(2 \mathrm{H}, \mathrm{m})$

Synthesis of (6-methacrylacrylamidohexanoyl)-O-THP-hydroxamic acid (THP-HX)
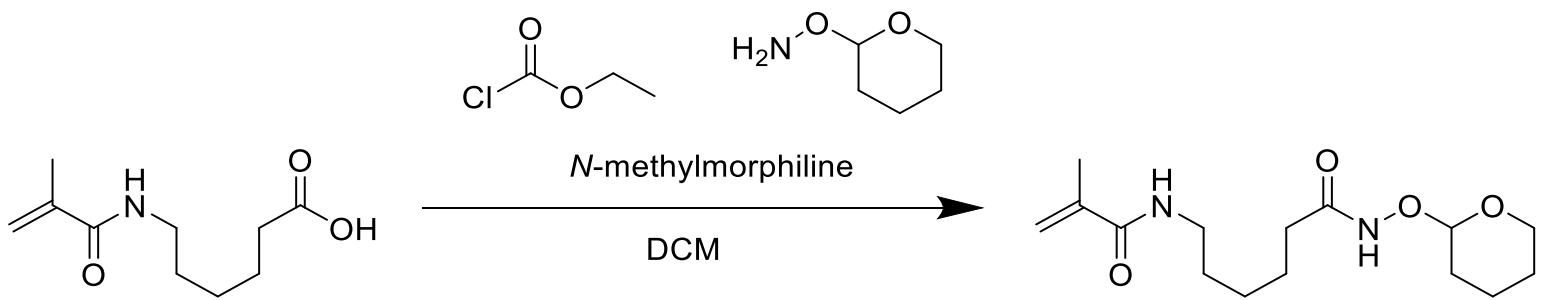

MHCA (1.2 g, $6 \mathrm{mmol})$ and N-methylmorphiline (MMP) $(902 \mu \mathrm{L}, 6.6 \mathrm{mmol}, 1.1 \mathrm{eq}$.$) was dissolved in$ $100 \mathrm{~mL}$ of DCM at $-20^{\circ} \mathrm{C}$. Ethyl chloroformate (ECF) $(696 \mu \mathrm{L}, 6.6 \mathrm{mmol}, 1.1 \mathrm{eq}$.) was added to the solution dropwise at $-20^{\circ} \mathrm{C}$ and stirred for $20 \mathrm{~min}$. O-THP hydroxylamine ( $798 \mathrm{mg}, 6 \mathrm{mmol}, 1 \mathrm{eq}$.) in $3 \mathrm{~mL}$ of DCM was added dropwise to the solution at $-20^{\circ} \mathrm{C}$ and stirred at r.t. for $3 \mathrm{~h}$. The solvent was evaporated and purified by TEA-neutralized silica gel column chromatography (EtOAc), resulting in white solid (Yield: $42 \%$ ).

${ }^{1} \mathrm{H}$ NMR $(500 \mathrm{MHz}, \mathrm{DMSO}-\mathrm{d6}): \delta(\mathrm{ppm})=10.88(1 \mathrm{H}, \mathrm{d}), 7.86(1 \mathrm{H}, \mathrm{m}), 5.61(1 \mathrm{H}, \mathrm{s}), 5.29(1 \mathrm{H}, \mathrm{s}), 4.79$ $(1 \mathrm{H}, \mathrm{s}), 3.91(1 \mathrm{H}, \mathrm{m}), 3.48(1 \mathrm{H}, \mathrm{m}), 3.07(2 \mathrm{H}, \mathrm{m}), 1.97(2 \mathrm{H}, \mathrm{m}), 1.83(3 \mathrm{H}, \mathrm{m}), 1.41-1.66(10 \mathrm{H}, \mathrm{m})$, $1.22(2 \mathrm{H}, \mathrm{m})$ 


\section{Synthesis of (6-methacrylacrylamidohexanoyl) -S-phenylalanine methyl ester (MHPM)}<smiles>C=C(C)C(=O)NCCCCCC(=O)O</smiles>

MHCA (1g, $3 \mathrm{mmol})$ and triethylamine $(1.53 \mathrm{~mL}, 6.6 \mathrm{mmol}, 2.2 \mathrm{eq})$ was dissolved in $100 \mathrm{~mL}$ of DCM at $-20^{\circ} \mathrm{C}$. ECF ( $\left.543 \mu \mathrm{L}, 3.3 \mathrm{mmol}, 1.1 \mathrm{eq}\right)$ was added to the solution dropwise at $-20^{\circ} \mathrm{C}$ and stirred for $20 \mathrm{~min}$. L-phenylalanine methyl ester $(1.1 \mathrm{~g}, 3 \mathrm{mmol}, 1 \mathrm{eq})$ in $3 \mathrm{~mL}$ of DMF was added dropwise to the solution at $-20^{\circ} \mathrm{C}$ and stirred at r.t. for $3 \mathrm{~h}$. The solution was washed with sat. $\mathrm{NH}_{4} \mathrm{Cl}$ and $\mathrm{NaHCO}_{3} 2$ times and dried over MgSO4. The crude was purified by silica gel column chromatography (EtOAc: hexane $=5: 1$ ), resulting in white solid (Yield: $82 \%$ ).

${ }^{1} \mathrm{H}$ NMR $(500 \mathrm{MHz}, \mathrm{DMSO}-\mathrm{d} 6): \delta(\mathrm{ppm})=8.23(1 \mathrm{H}, \mathrm{d}), 7.84(1 \mathrm{H}, \mathrm{m}), 7.20-7.29(5 \mathrm{H}, \mathrm{m}), 5.61(1 \mathrm{H}, \mathrm{S})$, $5.29(1 \mathrm{H}, \mathrm{s}), 4.45(1 \mathrm{H}, \mathrm{m}), 3.59(3 \mathrm{H}, \mathrm{s}), 3.03(3 \mathrm{H}, \mathrm{m}), 2.87(1 \mathrm{H}, \mathrm{m}), 2.03(2 \mathrm{H}, \mathrm{m}), 1.84(3 \mathrm{H}, \mathrm{m}), 1.38$ $(4 \mathrm{H}, \mathrm{m}), 1.12(2 \mathrm{H}, \mathrm{m})$

\section{Synthesis of (6-methacrylacrylamidohexanoyl) -S-phenylalanine (MHP)}<smiles>C=C(C)C(=O)NCCCCCC(=O)NC(Cc1ccccc1)C(=O)OC</smiles><smiles>C=C(C)C(=O)NCCCCCC(=O)NC(Cc1ccccc1)C(=O)O</smiles>

MHPM (1 g, $2.8 \mathrm{mmol}$ ) was dissolved in $9 \mathrm{~mL}$ of ethanol. $1 \mathrm{~mL}$ of $10 \mathrm{~N} \mathrm{NaOH}$ was added to the solution dropwise and stirred at r.t. for $2 \mathrm{~h} .50 \mathrm{~mL}$ of water was added to the reaction solution and ethanol was removed by rotary evaporator. The solution was acidified with $\mathrm{HCl}(\mathrm{pH}<2)$ and extracted with EtOAc. After the evaporation of EtOAc, white solid was obtained (yield $=92 \%$ ).

${ }^{1} \mathrm{H}$ NMR $(500 \mathrm{MHz}, \mathrm{DMSO}-d 6): \delta(\mathrm{ppm})=12.62(1 \mathrm{H}, \mathrm{s}), 8.07(1 \mathrm{H}, \mathrm{d}), 7.83(1 \mathrm{H}, \mathrm{s}), 7.18-7.27(5 \mathrm{H}, \mathrm{m})$, $5.61(1 \mathrm{H}, \mathrm{m}), 5.29(1 \mathrm{H}, \mathrm{m}), 4.42(1 \mathrm{H}, \mathrm{m}), 3.03(3 \mathrm{H}, \mathrm{m}), 2.83(1 \mathrm{H}, \mathrm{m}), 2.03(2 \mathrm{H}, \mathrm{m}), 1.84(3 \mathrm{H}, \mathrm{m}), 1.38$ $(4 \mathrm{H}, \mathrm{m}), 1.12(2 \mathrm{H}, \mathrm{m})$ 
Synthesis of (6-methacrylacrylamidohexanoyl)-S-phenylalanine-O-THP-hydroxamic acid (THPPHX)<smiles>C=C(C)C(=O)NCCCCCC(=O)NC(Cc1ccccc1)C(=O)O</smiles><smiles>[Y]P[IH+]P[I-]</smiles>

MHP ( $800 \mathrm{mg}, 2.3 \mathrm{mmol}$ ) and MMP (383 $\mu \mathrm{L}, 2.8 \mathrm{mmol}, 1.2 \mathrm{eq}$ ) were dissolved in $100 \mathrm{~mL}$ of DCM. ECF $(264 \mu \mathrm{L}, 2.5 \mathrm{mmol}, 1.1 \mathrm{eq})$ was added to the solution dropwise at $-20^{\circ} \mathrm{C}$ and stirred for $20 \mathrm{~min}$ at $-20^{\circ} \mathrm{C}$. O-THP hydroxylamine $(306 \mathrm{mg}, 2.3 \mathrm{mmol}, 1 \mathrm{eq}$ ) in DCM was added dropwise to the solution at $-20^{\circ} \mathrm{C}$ and stirred at r.t. for $3 \mathrm{~h}$. The solvent was evaporated and purified by TEAneutralized silica gel column chromatography (EtOAc : acetone $=9: 1$ ) resulting in white solid (Yield: 32\%).

${ }^{1} \mathrm{H}-\mathrm{NMR}(500 \mathrm{MHz}, \mathrm{DMSO}): 11.24(1 \mathrm{H}, \mathrm{d}), 8.09(1 \mathrm{H}, \mathrm{m}), 7.82(1 \mathrm{H}, \mathrm{s}), 7.10-7.41(5 \mathrm{H}, \mathrm{m}), 5.61(1 \mathrm{H}$, $\mathrm{s})$ ), $5.29(1 \mathrm{H}, \mathrm{s}), 4.76(1 \mathrm{H}, \mathrm{d}), 4.43(1 \mathrm{H}, \mathrm{m}), 3.91(1 \mathrm{H}, \mathrm{m}), 3.49(1 \mathrm{H}, \mathrm{m}), 3.03(2 \mathrm{H}, \mathrm{m}), 2.89(1 \mathrm{H}, \mathrm{m})$, $2.75(1 \mathrm{H}, \mathrm{m}), 2.01(2 \mathrm{H}, \mathrm{m}), 1.84(3 \mathrm{H}, \mathrm{s}), 1.31-1.71(10 \mathrm{H}, \mathrm{m}), 1.09(2 \mathrm{H}, \mathrm{m})$

\section{Synthesis of Methacrylamido-S-phenyl alanine methyl ester (MPheA methyl ester)}<smiles>C=C(C)C(=O)C(C)CC(C)C(=O)NC(Cc1ccccc1)C(=O)OC</smiles>

$\mathrm{L}$-phenylalanine methyl ester hydrochloride $(4.10 \mathrm{~g}, 18.99 \mathrm{mmol})$ and triethylamine $(3.53 \mathrm{~mL})$ were added into $75 \mathrm{~mL}$ of DCM. Methacryloyl chloride $(1.84 \mathrm{~mL}, 18.99 \mathrm{mmol})$ was added to the solution dropwise at $0^{\circ} \mathrm{C}$ and stirred at $0^{\circ} \mathrm{C}$ for $3 \mathrm{~h}$. The solution was washed with $1 \mathrm{~N} \mathrm{HCl}$, saturated $\mathrm{NaHCO}_{3}$ and the saturated $\mathrm{NaCl}$. The organic phase was dried over $\mathrm{MgSO} 4$. The product was purified by the column chromatography ( $n$-hexane / EtOAc gradient), resulting in white solid (Yield 43\%).

${ }^{1} \mathrm{H} \mathrm{NMR}\left(500 \mathrm{MHz}, \mathrm{CDCl}_{3}\right): \delta(\mathrm{ppm})=7.03-7.32(5 \mathrm{H}, \mathrm{m}), 5.65(1 \mathrm{H}, \mathrm{s}) 5.33(1 \mathrm{H}, \mathrm{s}), 4.82(1 \mathrm{H}, \mathrm{m}), 3.74$ $(3 \mathrm{H}, \mathrm{s}), 3.16(2 \mathrm{H}, \mathrm{d}), 1.91(3 \mathrm{H}, \mathrm{s})$ 


\section{Synthesis of Methacrylamido-S-phenyl alanine (MPheA)}

MPheA methyl ester (692 mg, $2.8 \mathrm{mmol}$ ) was dissolved in $9 \mathrm{~mL}$ of ethanol. $1 \mathrm{~mL}$ of $10 \mathrm{~N} \mathrm{NaOH}$ was added to the solution dropwise and stirred at r.t. for $2 \mathrm{~h} .50 \mathrm{~mL}$ of water was added to the reaction solution and ethanol was removed by rotary evaporator. The solution was acidified with $\mathrm{HCl}(\mathrm{pH}<2)$ and extracted with EtOAc. After the evaporation of EtOAc, white solid was obtained (yield $=58 \%$ ).
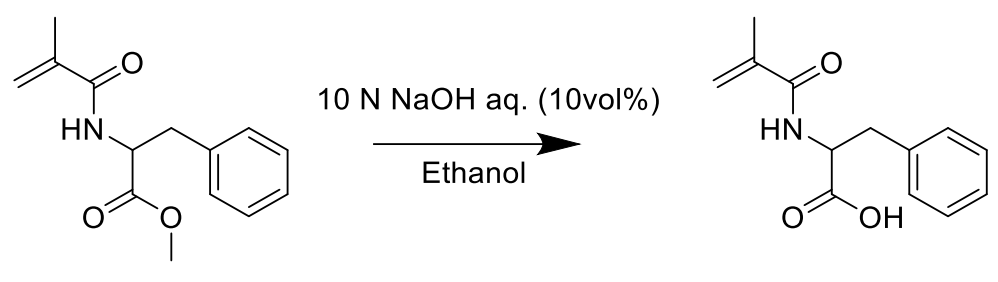

${ }^{1} \mathrm{H} \mathrm{NMR}\left(500 \mathrm{MHz}, \mathrm{CDCl}_{3}\right): \delta(\mathrm{ppm})=7.03-7.32(5 \mathrm{H}, \mathrm{m}), 5.65(1 \mathrm{H}, \mathrm{s}) 5.33(1 \mathrm{H}, \mathrm{s}), 4.79(1 \mathrm{H}, \mathrm{m}), 3.12$ $(2 \mathrm{H}, \mathrm{d}), 1.91(3 \mathrm{H}, \mathrm{s})$

Synthesis of Methacrylamido-S-phenyl alanine hydroxamic acid (C1PHX)<smiles>C=C(C)C(=O)NC(Cc1ccccc1)C(=O)O</smiles><smiles>CCOC(=O)Cl</smiles><smiles>C=C(C)C(=O)NC(Cc1ccccc1)C(=O)NOC1CCCCO1</smiles>

MPheA ( $800 \mathrm{mg}, 2.3 \mathrm{mmol}$ ) and MMP (383 $\mu \mathrm{L}, 2.8 \mathrm{mmol}, 1.2 \mathrm{eq}$ ) were dissolved in $100 \mathrm{~mL}$ of DCM. ECF ( $264 \mu \mathrm{L}, 2.5 \mathrm{mmol}, 1.1 \mathrm{eq})$ was added to the solution dropwise at $-20^{\circ} \mathrm{C}$ and stirred for $20 \mathrm{~min}$ at $-20^{\circ} \mathrm{C}$. O-THP hydroxylamine $(306 \mathrm{mg}, 2.3 \mathrm{mmol}, 1 \mathrm{eq}$ ) in DCM was added dropwise to the solution at $-20^{\circ} \mathrm{C}$ and stirred at r.t. for $3 \mathrm{~h}$. The solvent was evaporated and purified by TEAneutralized silica gel column chromatography (EtOAc: acetone $=8: 2$ ) resulting in white solid (Yield: 40\%).

${ }^{1} \mathrm{H}$ NMR $(500 \mathrm{MHz}$, DMSO-d6): $\delta(\mathrm{ppm})=7.10-7.41(5 \mathrm{H}, \mathrm{m}), 5.61(1 \mathrm{H}, \mathrm{s}), 5.29(1 \mathrm{H}, \mathrm{s}), 4.79(1 \mathrm{H}, \mathrm{d})$, $4.43(1 \mathrm{H}, \mathrm{m}), 3.91(1 \mathrm{H}, \mathrm{m}), 3.49(1 \mathrm{H}, \mathrm{m}), 2.90(1 \mathrm{H}, \mathrm{m}), 2.84(1 \mathrm{H}, \mathrm{m}), 1.91(3 \mathrm{H}, \mathrm{s}), 1.31-1.71(6 \mathrm{H}, \mathrm{m})$ 


\section{Synthesis of $\boldsymbol{N}$-isobutylacrylamide (IBAm)}

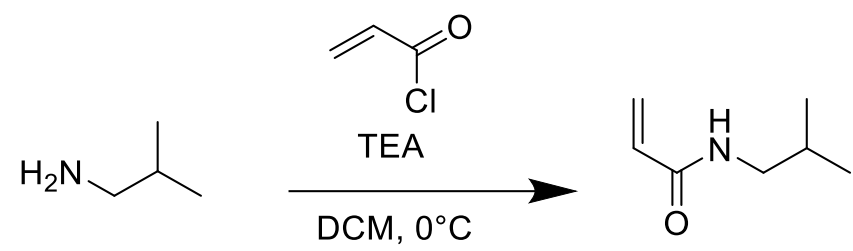

Isobutyl amine $(6.27 \mathrm{~mL}, 60 \mathrm{mmol})$ and triethylamine $(8.36 \mathrm{~mL}, 60 \mathrm{mmol})$ was dissolved in $50 \mathrm{~mL}$ of DCM at $0^{\circ} \mathrm{C}$. Acryloylcloride $(9.54 \mathrm{~mL}, 120 \mathrm{mmol})$ was added to the solution dropwise and stirred at $0^{\circ} \mathrm{C}$ for $2 \mathrm{~h}$. The solution was washed with $1 \mathrm{~N} \mathrm{HCl}$ and $1 \mathrm{~N} \mathrm{NaOH} 2$ times and dried over MgSO4. The organic phase was evaporated resulting in colorless oil (Yield: 81\%)

${ }^{1} \mathrm{H}$ NMR $(500 \mathrm{MHz}, \mathrm{DMSO}-\mathrm{d} 6): \delta(\mathrm{ppm})=8.05(1 \mathrm{H}, \mathrm{s}), 6.22(1 \mathrm{H}, \mathrm{dd}), 6.05(1 \mathrm{H}, \mathrm{dd}), 5.54(1 \mathrm{H}, \mathrm{dd})$, $2.96(2 \mathrm{H}, \mathrm{t}), 1.71(1 \mathrm{H}, \mathrm{m}), 0.84(6 \mathrm{H}, \mathrm{d})$

\section{Synthesis of $\mathbf{N}$-acrylamido-S-leuicine (ALeu)}<smiles>C=CC(=O)NC(CC(C)C)C(=O)O</smiles>

L-Leucine $(2.62 \mathrm{~g}, 20 \mathrm{mmol}$ ) was dissolved in $20 \mathrm{~mL}$ of $2 \mathrm{M}$ potassium hydroxide aqueous solution at $0^{\circ} \mathrm{C}$. Acryloylchloride $(1.75 \mathrm{~mL}, 22 \mathrm{mmol})$ was added to the solution dropwise and stirred at $0^{\circ} \mathrm{C}$ for $2 \mathrm{~h}$. The solution was acidified using $5 \mathrm{~N} \mathrm{HCl}(\mathrm{PH}<2)$, resulting in a white waxy solid. The solid was dissolved in warm water and filtered. After the filtrate was cooled down, the product (white waxy solids) was collected by filtration (Yield: $52.4 \%$ )

${ }^{1} \mathrm{H}$ NMR $(500 \mathrm{MHz}, \mathrm{DMSO}-\mathrm{d} 6): \delta(\mathrm{ppm})=8.40(1 \mathrm{H}, \mathrm{d}), 6.34(1 \mathrm{H}, \mathrm{dd}), 6.14(1 \mathrm{H}, \mathrm{dd}), 5.66(1 \mathrm{H}, \mathrm{dd})$, $4.34(1 \mathrm{H}, \mathrm{m}), 1.56(3 \mathrm{H}, \mathrm{m}), 0.90(6 \mathrm{H}, \mathrm{q})$ 


\section{Synthesis of $\mathbf{N}$-acrylamido-S-phenylalanine (APhe)}<smiles>NC(Cc1ccccc1)C(=O)O</smiles><smiles>C=CC(=O)Cl</smiles>

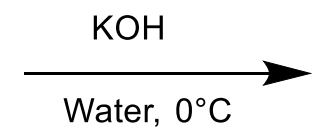<smiles>C=CC(=O)NC(Cc1ccccc1)C(=O)O</smiles>

L-phenyl alanine $(10.8 \mathrm{~g}, 65 \mathrm{mmol})$ was dissolved in $100 \mathrm{~mL}$ of $2 \mathrm{M}$ potassium hydroxide aqueous solution at $0^{\circ} \mathrm{C}$. Acryloylchloride $(5.2 \mathrm{~mL}, 67 \mathrm{mmol})$ was added to the solution dropwise and stirred at $0^{\circ} \mathrm{C}$ for $2 \mathrm{~h}$. The solution was acidified using $5 \mathrm{~N} \mathrm{HCl}(\mathrm{PH}<2)$ and a precipitated white solid was filtered and dried (yield: $47 \%$ ).

${ }^{1} \mathrm{H}$ NMR $(500 \mathrm{MHz}$, DMSO-d6): $\delta(p p m)=12.73(1 \mathrm{H}, \mathrm{s}), 8.41(2 \mathrm{H}, \mathrm{d}), 7.18-7.29(5 \mathrm{H}, \mathrm{m}), 6.24(1 \mathrm{H}$, dd), $6.03(1 \mathrm{H}, \mathrm{dd}) 5.56(1 \mathrm{H}, \mathrm{dd}), 4.51(1 \mathrm{H}, \mathrm{m}), 3.07(1 \mathrm{H}, \mathrm{q}), 2.87(1 \mathrm{H}, \mathrm{q})$

\section{Synthesis of $\mathbf{N}$-benzamidineacrylamide (ABA)}<smiles>N=C(N)c1ccc(N)cc1</smiles>

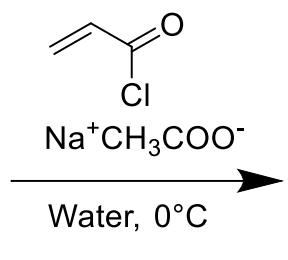<smiles>C=CC(=O)Nc1ccc(C(=N)N)cc1</smiles>

ABA was synthesized as earlier reported ${ }^{\mathrm{S} 1} .2 \mathrm{~g}$ of 4 -amino benzamidine $(9.6 \mathrm{mmol})$ and $34 \mathrm{~g}$ of sodium acetate $(0.41 \mathrm{~mol})$ were dissolved in $200 \mathrm{~mL}$ water at $0^{\circ} \mathrm{C}$. Acryloylchloride $(49 \mathrm{mmol})$ was added to the solution dropwise and stirred at $0^{\circ} \mathrm{C}$ for $1 \mathrm{~h}$. The solution was acidified using $5 \mathrm{~N} \mathrm{HCl}$ $(\mathrm{PH}<4)$ and precipitation was filtered. The precipitate was redissolved in hot water. Hydrochloric acid was again added to $\mathrm{pH} 1.0$, until precipitation was observed. The precipitate was collected by filtration and dried and dried (yield: 53\%).

${ }^{1} \mathrm{H}$ NMR $(500 \mathrm{MHz}$, DMSO-d6): $\delta(\mathrm{ppm})=10.87(1 \mathrm{H}, \mathrm{s}), 8.99(3 \mathrm{H}, \mathrm{d}), 7.91(2 \mathrm{H}, \mathrm{d}), 7.83(2 \mathrm{H}, \mathrm{d})$, $6.55(1 \mathrm{H}, \mathrm{dd}), 6.30(1 \mathrm{H}, \mathrm{dd}), 5.82(1 \mathrm{H}, \mathrm{dd})$ 


\section{SYNTHESIS AND CHARACTERIZATION OF NANOPARTICLE}

\section{Synthesis of nanoparticles}

Co-monomers and $1 \mathrm{mM}$ surfactant were dissolved in $30 \mathrm{~mL}$ of water. Nitrogen was bubbled through the reaction mixture for $30 \mathrm{~min}$. Following the addition of initiator, the polymerization was carried out for $3 \mathrm{~h}$ under a nitrogen atmosphere. The polymerized solution was purified by dialysis against an excess amount of water (changed more than 2 times a day) for 4 days. The yield of NPs was determined by measuring the weight of NPs obtained by lyophilization of the dialyzed solution. Polymerization conditions are shown in table S1. Hydrodynamic diameter, Pdl measured by the dynamic light scattering (DLS) and inhibition (\%) of NPs are shown in table S2.

\section{Deprotection of THP following polymerization}

The NP solution was incubated in acidic condition (100 mM HCi) in the presence of SDS $(4 \mathrm{mM})$ at r.t. for 15 hours. The NP solution was neutralized and purified by dialysis against an excess amount of $1 \mathrm{mM} \mathrm{NaHCO}_{3}$ ( 2 days), $1 \mathrm{mM} \mathrm{HCl}$ (1 days) and water (2 days) (changed more than 3 times a day). The concentration of NPs was determined by measuring the weight of NPs obtained by lyophilization of the dialyzed solution. The deprotection was confirmed from disappearance of protons of THP groups ( $b$ and a protons in Figure S1). We also confirmed that commoners were incorporated in NP16 as designed (NIPAm: APhe: PHX = e: b: $c=2: 2: 1$ ). Incorporation ratio of BIS could not be determined due to low loading amount (2\%).
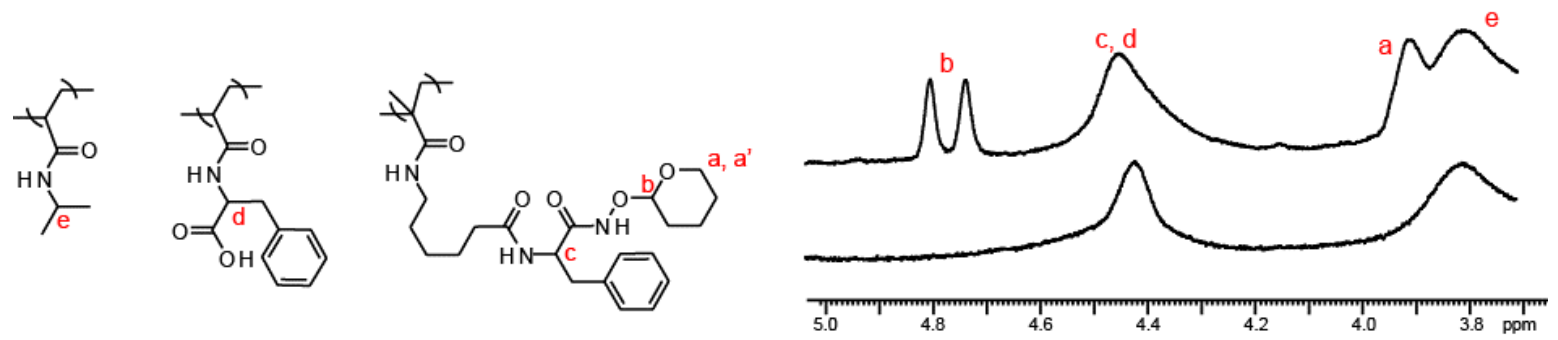

Figure S1. ${ }^{1} \mathrm{H}$ NMR (d6-DMSO, $25^{\circ} \mathrm{C}$ ) spectrum of NP16. 
Table S1. Chemical composition and polymerization condition of nanoparticles

\begin{tabular}{|c|c|c|c|c|c|c|c|c|c|c|c|c|c|c|c|c|c|}
\hline & \multicolumn{12}{|c|}{ Feed (mol\%) } & \multirow{2}{*}{$\begin{array}{c}\text { Monomer } \\
\text { concentration } \\
(\mathrm{mM})\end{array}$} & \multirow{2}{*}{ Surfactant } & \multirow{2}{*}{ Initiator } & \multirow{2}{*}{$\begin{array}{c}\text { Organic } \\
\text { solvent }^{\mathrm{a}}\end{array}$} & \multirow{2}{*}{$\begin{array}{c}\text { Temperature } \\
\left({ }^{\circ} \mathrm{C}\right)\end{array}$} \\
\hline & NIPAm & BIS & $\begin{array}{l}\text { THP- } \\
\text { PHX }\end{array}$ & $\begin{array}{l}\text { THP- } \\
\text { C1PHX }\end{array}$ & $\begin{array}{c}\text { THP- } \\
\text { HX }\end{array}$ & MHPM & IBAm & PAm & ALeu & APhe & ABA & AAC & & & & & \\
\hline NP1 & 73 & 2 & 20 & 0 & 0 & 0 & 0 & 0 & 0 & 0 & 0 & 5 & 65 & $\begin{array}{l}\text { SDS, } \\
1 \mathrm{mM}\end{array}$ & $\begin{array}{c}\text { APS/TEMED } \\
20 \mathrm{mM} / 20 \mathrm{mM}\end{array}$ & $\begin{array}{l}\text { Acetone, } \\
5 \text { vol\% }\end{array}$ & 40 \\
\hline NP2 & 73 & 2 & 0 & 20 & 0 & 0 & 0 & 0 & 0 & 0 & 0 & 5 & 32.5 & $\begin{array}{c}\text { SDS } \\
1 \mathrm{mM}\end{array}$ & $\begin{array}{c}\text { APS } / \text { TEMED } \\
20 \mathrm{mM} / 20 \mathrm{mM}\end{array}$ & $\begin{array}{l}\text { Acetone, } \\
5 \text { vol\% }\end{array}$ & 40 \\
\hline NP3 & 73 & 2 & 0 & 0 & 20 & 0 & 0 & 0 & 0 & 0 & 0 & 5 & 32.5 & $\begin{array}{l}\text { SDS, } \\
1 \mathrm{mM}\end{array}$ & $\begin{array}{c}\text { APS/TEMED } \\
20 \mathrm{mM} / 20 \mathrm{mM}\end{array}$ & $\begin{array}{l}\text { Acetone, } \\
5 \text { vol\% }\end{array}$ & 40 \\
\hline NP4 & 73 & 2 & 0 & 0 & 0 & 20 & 0 & 0 & 0 & 0 & 0 & 5 & 32.5 & $\begin{array}{c}\text { SDS, } \\
1 \mathrm{mM}\end{array}$ & $\begin{array}{c}\text { APS/TEMED } \\
20 \mathrm{mM} / 20 \mathrm{mM}\end{array}$ & $\begin{array}{l}\text { Acetone, } \\
5 \text { vol\% }\end{array}$ & 40 \\
\hline NP5 & 93 & 2 & 0 & 0 & 0 & 0 & 0 & 0 & 0 & 0 & 0 & 5 & 65 & $\begin{array}{l}\text { SDS, } \\
1 \mathrm{mM}\end{array}$ & $\begin{array}{c}\text { APS, } \\
2 \mathrm{mM}\end{array}$ & - & 70 \\
\hline NP6 & 53 & 2 & 0 & 0 & 0 & 0 & 40 & 0 & 0 & 0 & 0 & 5 & 65 & $\begin{array}{l}\text { SDS, } \\
1 \mathrm{mM}\end{array}$ & $\begin{array}{l}\text { APS, } \\
2 \mathrm{mM}\end{array}$ & $\begin{array}{l}\text { Methanol } \\
5 \text { vol\% }\end{array}$ & 40 \\
\hline NP7 & 53 & 2 & 0 & 0 & 0 & 0 & 0 & 40 & 0 & 0 & 0 & 5 & 65 & $\begin{array}{l}\text { SDS, } \\
1 \mathrm{mM}\end{array}$ & $\begin{array}{l}\text { APS, } \\
2 \mathrm{mM}\end{array}$ & $\begin{array}{l}\text { Acetone, } \\
5 \text { vol\% }\end{array}$ & 70 \\
\hline NP8 & 58 & 2 & 0 & 0 & 0 & 0 & 0 & 0 & 40 & 0 & 0 & 0 & 65 & $\begin{array}{l}\mathrm{SDS}, \\
1 \mathrm{mM}\end{array}$ & $\begin{array}{l}\text { APS, } \\
2 \mathrm{mM}\end{array}$ & $\begin{array}{l}\text { Methanol, } \\
5 \text { vol\% }\end{array}$ & 70 \\
\hline NP9 & 58 & 2 & 0 & 0 & 0 & 0 & 0 & 0 & 0 & 40 & 0 & 0 & 65 & $\begin{array}{l}\text { SDS, } \\
1 \mathrm{mM}\end{array}$ & $\begin{array}{l}\text { APS, } \\
2 \mathrm{mM}\end{array}$ & - & 70 \\
\hline NP10 & 58 & 2 & 0 & 0 & 0 & 0 & 0 & 0 & 0 & 0 & 40 & 0 & 65 & $\begin{array}{l}\text { CTAB, } \\
1 \mathrm{mM}\end{array}$ & $\begin{array}{l}\text { AIBN, } \\
2 \mathrm{mM}\end{array}$ & $\begin{array}{l}\text { Acetone, } \\
1 \text { vol\%- }\end{array}$ & 70 \\
\hline NP11 & 83 & 2 & 10 & 0 & 0 & 0 & 0 & 0 & 0 & 0 & 0 & 5 & 32.5 & $\begin{array}{l}\text { SDS, } \\
1 \mathrm{mM}\end{array}$ & $\begin{array}{c}\text { APS/TEMED } \\
20 \mathrm{mM} / 20 \mathrm{mM}\end{array}$ & $\begin{array}{l}\text { Acetone, } \\
5 \text { vol\% }\end{array}$ & 40 \\
\hline NP12 & 78 & 2 & 0 & 0 & 0 & 0 & 0 & 0 & 0 & 20 & 0 & 0 & 65 & $\begin{array}{l}\text { SDS, } \\
1 \mathrm{mM}\end{array}$ & $\begin{array}{c}\text { APS/TEMED } \\
20 \mathrm{mM} / 20 \mathrm{mM}\end{array}$ & $\begin{array}{l}\text { Acetone, } \\
5 \text { vol\% }\end{array}$ & 40 \\
\hline NP13 & 68 & 2 & 10 & 0 & 0 & 0 & 0 & 0 & 0 & 20 & 0 & 0 & 32.5 & $\begin{array}{l}\text { SDS, } \\
1 \mathrm{mM}\end{array}$ & $\begin{array}{c}\text { APS/TEMED } \\
20 \mathrm{mM} / 20 \mathrm{mM}\end{array}$ & $\begin{array}{l}\text { Acetone, } \\
15 \text { vol\% }\end{array}$ & 40 \\
\hline NP14 & 48 & 2 & 10 & 0 & 0 & 0 & 0 & 0 & 0 & 20 & 0 & 0 & 21.7 & $\begin{array}{l}\text { SDS, } \\
1 \mathrm{mM}\end{array}$ & $\begin{array}{c}\text { APS/TEMED } \\
20 \mathrm{mM} / 20 \mathrm{mM}\end{array}$ & $\begin{array}{l}\text { Acetone, } \\
15 \text { vol\% }\end{array}$ & 40 \\
\hline NP15 & 58 & 2 & 10 & 0 & 0 & 0 & 0 & 0 & 0 & 40 & 0 & 0 & 21.7 & $\begin{array}{l}\text { SDS, } \\
1 \mathrm{mM}\end{array}$ & $\begin{array}{c}\text { APS/TEMED } \\
20 \mathrm{mM} / 20 \mathrm{mM}\end{array}$ & $\begin{array}{l}\text { Acetone, } \\
15 \text { vol\% }\end{array}$ & 40 \\
\hline NP16 & 38 & 2 & 20 & 0 & 0 & 0 & 0 & 0 & 0 & 40 & 0 & 0 & 12.65 & $\begin{array}{l}\text { SDS, } \\
1 \mathrm{mM}\end{array}$ & $\begin{array}{c}\text { APS/TEMED } \\
20 \mathrm{mM} / 20 \mathrm{mM}\end{array}$ & $\begin{array}{l}\text { Acetone, } \\
15 \text { vol\% }\end{array}$ & 40 \\
\hline
\end{tabular}

(a) Co-monomers (THP-PHX, THP-HX, MHPM, THP-C1PHX, IBAm, PAm and ALeu,) and AIBN with low water solubility was dissolved in a small amount of organic solvent and added to the monomer solution. 
Table S2. Hydrodynamic diameter and poly dispersity index (Pdl) in PBS (pH 7.5, $10 \mathrm{mM}$ phosphate containing $147 \mathrm{mM} \mathrm{NaCl}$ and $3 \mathrm{mM} \mathrm{KCl)}$ at $37^{\circ} \mathrm{C}$, yield (\%) and inhibition (\%) of NPs.

\begin{tabular}{ccccc}
\hline & Diameter $(\mathbf{n m})$ & Pdl & Yield (\%) & Inhibition (\%) \\
\hline NP1 & $541 \pm 86$ & $0.44 \pm 0.02$ & 73 & $27.7 \pm 7.1$ \\
NP2 & $280 \pm 15$ & $0.25 \pm 0.01$ & 78 & $6.2 \pm 5.2$ \\
NP3 & $170 \pm 9$ & $0.27 \pm 0.01$ & 77 & $0.2 \pm 0.5$ \\
NP4 & $171 \pm 9$ & $0.07 \pm 0.01$ & 78 & $-6.9 \pm 1.8$ \\
NP5 & $115 \pm 1$ & $0.06 \pm 0.01$ & 65 & $-0.4 \pm 3.6$ \\
NP6 & $114 \pm 4$ & $0.08 \pm 0.02$ & 82 & $-4.1 \pm 3.1$ \\
NP7 & $72 \pm 4$ & $0.04 \pm 0.07$ & $0.2 \pm 1.4$ \\
NP8 & $216 \pm 2$ & $0.3 \pm 0.01$ & 85 & $16.6 \pm 0.5$ \\
NP9 & $213 \pm 1$ & $0.06 \pm 0.01$ & 80 & $33.6 \pm 4.5$ \\
NP10 & N.A. ${ }^{a}$ & & 70 & $29.2 \pm 8.2$ \\
NP11 & & $0.35 \pm 0.002$ & 58 & $14.6 \pm 3.1$ \\
NP12 & $438 \pm 28$ & $0.04 \pm 0.003$ & 75 & $9.0 \pm 2.1$ \\
NP13 & $193 \pm 6$ & $0.24 \pm 0.08$ & 82 & $61.0 \pm 3.4$ \\
NP14 & $260 \pm 91$ & $0.48 \pm 0.15$ & 74 & $62.0 \pm 3.4$ \\
\hline NP15 & $469 \pm 115$ & $0.54 \pm 0.06$ & 72 & $85.8 \pm 4.5$ \\
NP16 & $495 \pm 207$ & $0.23 \pm 0.02$ & 84 & $81.5 \pm 2.1$ \\
\hline
\end{tabular}

(a) N.A. not applicable. Polymers was too poly disperse or aggregated in experimental condition. 


\section{Size measurement of NP7 (PAm 40\% and AAc 5\%) and NP9 (APhe 40\%) in PBS and water}

To reveal the importance of bifunctional groups for the enzyme surface binding, hydrodynamic diameter of NPs was measured by the dynamic light scattering (Figure S2).

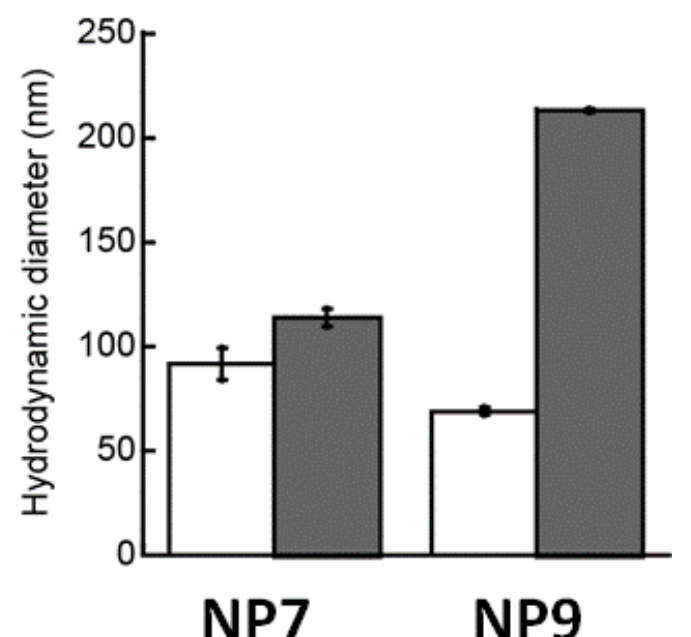

Figure S2. Hydrodynamic diameter of NP7 and NP9 in water (white) and PBS (pH 7.5, $10 \mathrm{mM}$ phosphate containing $147 \mathrm{mM} \mathrm{NaCl}$ and $3 \mathrm{mM} \mathrm{KCl}$, gray) at $37^{\circ} \mathrm{C}$. The concentration of NPs were $0.1 \mathrm{gL}^{-1}$.

\section{SVMPS INHIBITION ASSAY}

\section{Evaluation of inhibition (\%)}

The mixture of NPs $(1 \mathrm{mg} / \mathrm{mL})$ and crotalus atrox venom $(0.1 \mathrm{mg} / \mathrm{mL})$ in PBS $(\mathrm{pH} 7.5,10 \mathrm{mM}$ phosphate containing $137 \mathrm{mM} \mathrm{NaCl}$ and $3 \mathrm{mM} \mathrm{KCl}$ ) was incubated at $37^{\circ} \mathrm{C}$ for $30 \mathrm{~min} .100 \mu \mathrm{L}$ of azocasein (10 mg/L in PBS) was added to $100 \mu \mathrm{L}$ of NP-venom mixture and incubated at $37^{\circ} \mathrm{C}$ for $90 \mathrm{~min}$. After stopping the reaction with $200 \mu \mathrm{L}$ of $5 \mathrm{wt} \%$ trichloroacetic acid, followed by centrifugation ( $20 \mathrm{kG}, 10 \mathrm{~min}$ ), $50 \mu \mathrm{L}$ of supernatant was mixed with $50 \mu \mathrm{L}$ of $0.5 \mathrm{M} \mathrm{NaOH}$, and the absorbance at $450 \mathrm{~nm}$ was recorded. Inhibition (\%) was obtained from the equation (1) using 1 mM EDTA as a positive control. PBS buffer with venom alone. When inhibition (\%) was evaluated in the presence of human serum, controls also contained same volume of human serum.

$$
\begin{aligned}
& \text { Inhibition (\%) } \\
& =100 \times \frac{\left(\text { Absorbance }_{\text {buffer }}-\text { Absorbance }\right)}{\left(\text { Absorbance }_{\text {buffer }}-\text { Absorbance }_{\text {EDTA }}\right)}
\end{aligned}
$$




\section{Evaluation of IC50 of NP}

The inhibition (\%) by various concentration of NPs $(0.02-1.4 \mathrm{mg} / \mathrm{mL})$ was evaluated by the azocasein assay as mentioned above. Whole venom from Crotalus atrox, Bitis arietans, Bitis gabonica, Echis ocellatus and Echis carinatus were utilized as target venom. IC50 was obtained from curve fitting using equation (2).

$$
\text { Inhibiion }(\%)=100 /\left(1+\left(\frac{\mathrm{IC}_{50}}{[\mathrm{NP}]}\right)^{n}\right)
$$

\section{Evaluation of inhibitory kinetics of NP}

To assess the inhibitory kinetics of NPs, the time of enzymatic reaction was reduced from 90 to 9 $\mathrm{min}$, instead venom concentration was increased from 0.1 to $1 \mathrm{mg} / \mathrm{mL}$ to amplify the absorbance. The mixture of NPs $(1 \mathrm{mg} / \mathrm{mL})$ and crotalus atrox venom $(1 \mathrm{mg} / \mathrm{mL})$ in PBS was incubated at $37^{\circ} \mathrm{C}$ for various periods. $100 \mu \mathrm{L}$ of azocasein (10 mg/L in PBS) was added to $100 \mu \mathrm{L}$ of NP-venom mixture and incubated at $37^{\circ} \mathrm{C}$ for $9 \mathrm{~min}$. After stopping the reaction with $200 \mu \mathrm{L}$ of $5 \mathrm{wt} \%$ trichloroacetic acid, followed by centrifugation ( $20 \mathrm{kG}, 10 \mathrm{~min}$ ), $50 \mu \mathrm{L}$ of supernatant was mixed with $50 \mu \mathrm{L}$ of $0.5 \mathrm{M} \mathrm{NaOH}$, and the absorbance at $450 \mathrm{~nm}$ was recorded. Inhibition (\%) was obtained from the equation (1) using 1 mM EDTA as a positive control (Figure S3).

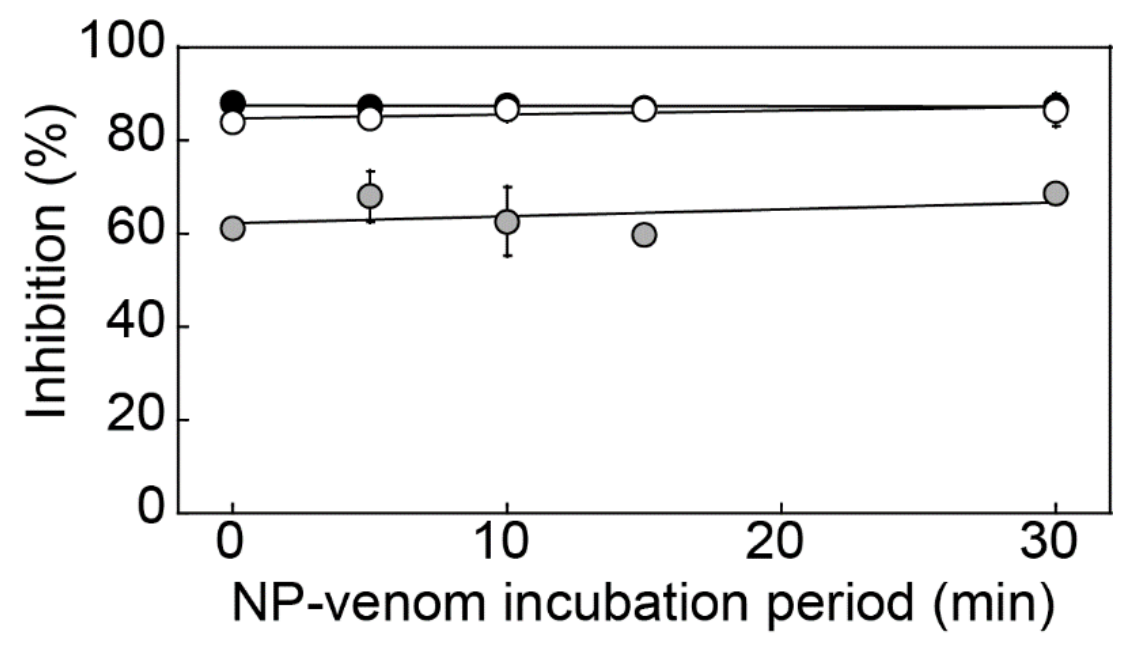

Figure S3. Inhibition (\%) of NP16 for venom from Crotalus atrox as a function of NP-venom incubation period. NP was mixed with venom in the presence (white) or absence (black) of 25 vol\% of human serum. NP and $25 \mathrm{vol} \%$ of human serum were pre-incubated for $30 \mathrm{~min}$ at $37^{\circ} \mathrm{C}$, then venom was added to the mixture (gray). 


\section{DOCKING SIMULATION}

Docking simulations were performed with the Autodock4 $\mathrm{Zn}$ force field implemented in the Autodock4 soft-ware. A crystal structure of PI SVMP (PDB ID: 2W13) and ligand analogs (Figure S4) were utilized as a receptor and ligands, respectively. In simulations, grid was fixed for each ligand that covers the active site of the receptor. The calculation was performed 100 times for each ligand. Obtained solutions of each ligand were classified into clusters based on RMSD and shown as histogram in the main text. A typical docked model of PHX and enzyme revealed the PHX group binds to both $\mathrm{Zn}$ and S-pocket (Figure S5a). The alkyl chain was manually added to the PHX in the docked model to visualize the importance of six-carbon spacer of PHX (Figure S5b).<smiles>CCC(C)(CC)C(=O)NCCCCCC(=O)NC(Cc1ccccc1)C(=O)NO</smiles>

PHX-analog<smiles>CCC(C)(CC)C(=O)NCCCCCC(=O)NO</smiles>

HX-analog<smiles>CCC(C)(CC)C(=O)NCCCCCC(=O)NC(Cc1ccccc1)C(=O)OC</smiles>

MHPM-analog

Figure S4. Ligand analogs utilized in the docking simulation.

(a)

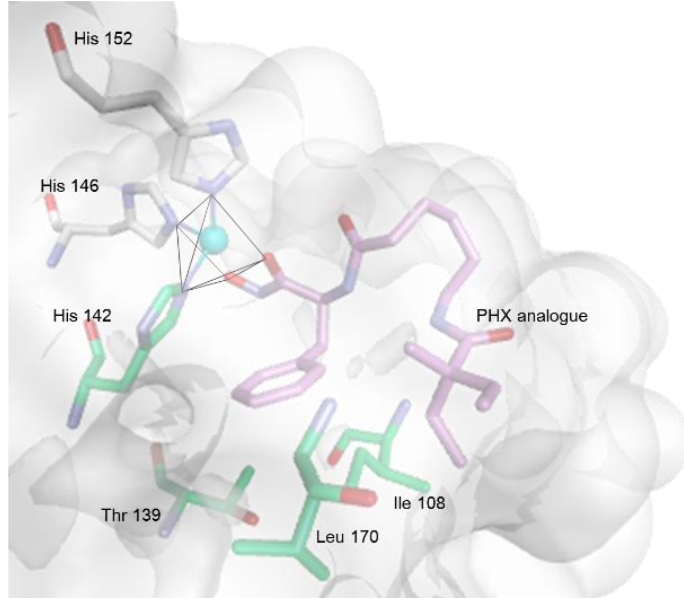

(b)

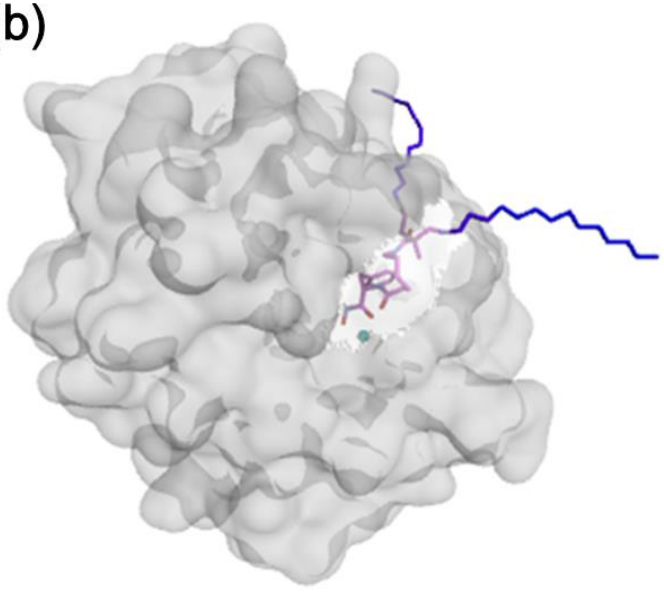

Figure S5. (a) The docked model of PHX (magenta) and enzyme. Residues in S-pocket are green colored. The catalytic zinc cation ( $\mathrm{Zn}$ ) is shown as a light blue sphere. (b) Alkyl carbons were manually added to PHX to show the importance of six-carbon spacer (blue). 


\section{FILTER EXPERIMENT}

Before the protein sequestration experiment, NPs solution in PBS $(\mathrm{pH} 7.5,10 \mathrm{mM}$ phosphate containing $147 \mathrm{mM} \mathrm{NaCl}$ and $3 \mathrm{mM} \mathrm{KCl}$ ) was pre-filtered 3 times using Nanosep (300 kDa, $20 \mathrm{~min}$, $5 \mathrm{kG})$ and concentration of NP was determined from UV absorbance at $260 \mathrm{~nm}$. NPs $(1 \mathrm{mg} / \mathrm{mL})$ and venom $(1 \mathrm{mg} / \mathrm{mL})$ were mixed and incubated at $37^{\circ} \mathrm{C}$ for $30 \mathrm{~min}$ in PBS. Then, $100 \mu \mathrm{L}$ of the mixture solution was filtered. The NP-protein complex on the filter was washed using same volume of PBS and eluted. This process was repeated 10 times. The solution that passed through the filter was diluted 10 times using PBS and SVMP enzymatic activity was quantified as mentioned above. The sequestration capacity of NP was also evaluated by a pull-down filter experiment. 1 $\mathrm{mg} / \mathrm{mL}$ of NP and $0.1,1,10$ or $50 \mathrm{mg} / \mathrm{mL}$ of venom was mixed and incubated at $37^{\circ} \mathrm{C}$ for $30 \mathrm{~min}$. Then, $100 \mu \mathrm{L}$ of the mixture solution was filtered. The solution that passed through the filter was $1,10,100$ or 500 times diluted using PBS and SVMP proteolytic activity was quantified as mentioned above (Figure S6).

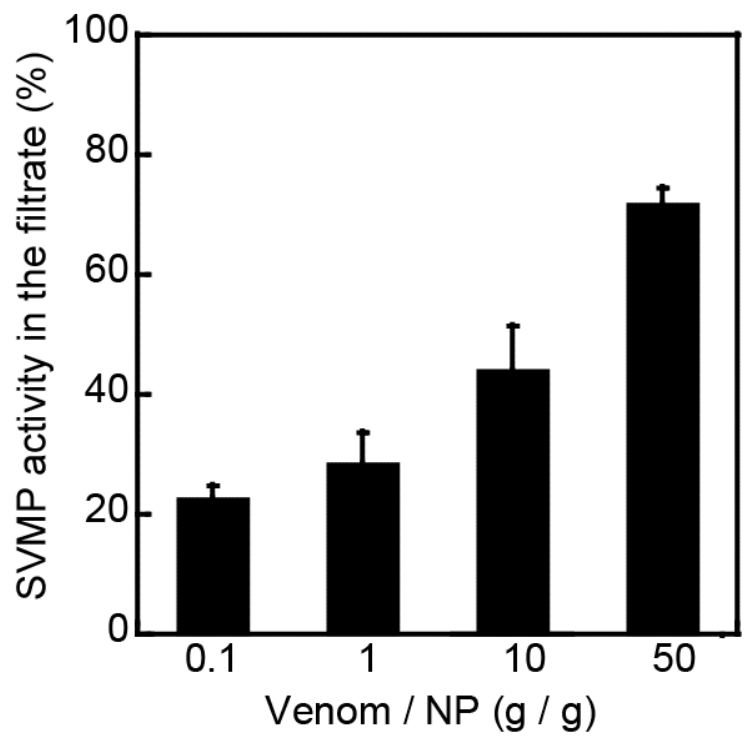

Figure S6. SVMPs sequestration by NP16 


\section{SDS-PAGE VISUALIZATION AND MASS-SPECTROMETRIC ANALYSIS}

\section{SDS-PAGE visualization}

Before the protein sequestration experiment, NPs solution in PBS ( $\mathrm{pH} 7.5,10 \mathrm{mM}$ phosphate containing $147 \mathrm{mM} \mathrm{NaCl}$ and $3 \mathrm{mM} \mathrm{KCl}$ ) was pre-filtered 3 times using Nanosep ( $300 \mathrm{kDa}, 20 \mathrm{~min}$, $5 \mathrm{kG}$ ) and concentration of NP was determined from UV absorbance at $260 \mathrm{~nm}$. NPs $(1 \mathrm{mg} / \mathrm{mL})$ and venom $(5 \mathrm{mg} / \mathrm{mL})$ were mixed and incubated in PBS at $37^{\circ} \mathrm{C}$ for $30 \mathrm{~min}$. Then, $100 \mu \mathrm{L}$ of the mixture solution was filtered and the NP-protein complex on the filter was washed using same volume of PBS and eluted. This process was repeated 10 times. Proteins in the filtrate was visualized by SDS-PAGE (200 V). After 10 times washing and elution processes, strongly bound proteins on NP was eluted using LDS sample buffer containing reducing agent and visualized (Figure S7). The samples were heated at $95^{\circ} \mathrm{C}$ for $5 \mathrm{~min}$ before the electrophoresis.

\section{Mass-spectrometric analysis}

The stained gel band 1 and band 2 were excised into a small pieces. The gel was $1 \mathrm{mmersed}$ in $1 \mathrm{~mL}$ of destain solution (1:1 Acetonitrile (ACN) and $200 \mathrm{mM}$ Ammonium Bicarbonate $(A B C)$ ). After destain and discard of destain solution, $100 \mu \mathrm{L}$ of dithiothreitol (DTT) in $A B C(15 \mathrm{mg} / \mathrm{mL})$ was added to the gel and heated at $80^{\circ} \mathrm{C}$ for $10 \mathrm{~min}$. After discard of DTT solution, $100 \mu \mathrm{L}$ of iodoacetamide (IAA) in $A B C(18 \mathrm{mg} / \mathrm{mL})$ was added to the gel and stored in the dark for 1 hour at r.t. IAA solution was replaced with $500 \mu \mathrm{L}$ of $50 \mathrm{mM} \mathrm{ABC}$ and incubated for $15 \mathrm{~min}$. ABC solution was replaced with $\sim 500 \mu \mathrm{L}$ destain solution and incubated for $15 \mathrm{~min}$, then replaced with $\mathrm{ACN}$ and incubated for $5 \mathrm{~min}$ or until gel is shrunk and white. The gel was dried in a SpeedVac for $3 \mathrm{~min}$. 100-250 ng of trypsin gold in $50 \mathrm{mM} \mathrm{ABC}$ was added to dried gel. Digestion was proceeded at $37^{\circ} \mathrm{C}$ for 18 hours. Hydrolyzed peptides was extracted with $20 \mu \mathrm{L}$ of $0.1 \%$ formic acid for $15 \mathrm{~min}$. Mass spectrum of extracted peptides was obtained using 2, 5-Dihydroxybenzoic acid (DHB) as a matrix (Figure S8). The data was analyzed in MASCOT (sequence query) using the Swiss-Prot database (Chordata (vertebrates and relatives)) with carbamidomethyl-cysteine and oxidation of methionine and tryptophan as variable modifications, one missed cleavage site allowed. The analysis identified PIII SVMP (VAP2B and VAP2A) and PI SVMP (atroxase) in band1 and band2, respectively, as significant matched proteins $(p<0.05)$. The homology search using BLAST also found other PI SVMP (Ht-e and atrolysin-B) in band 2 showing comparable sequence coverage (\%) with atroxase. As a result, most major signals in both band 1 and band 2 could be matched with peptides from PI SVMP and PIII SVMP family proteins (Figure S8). 


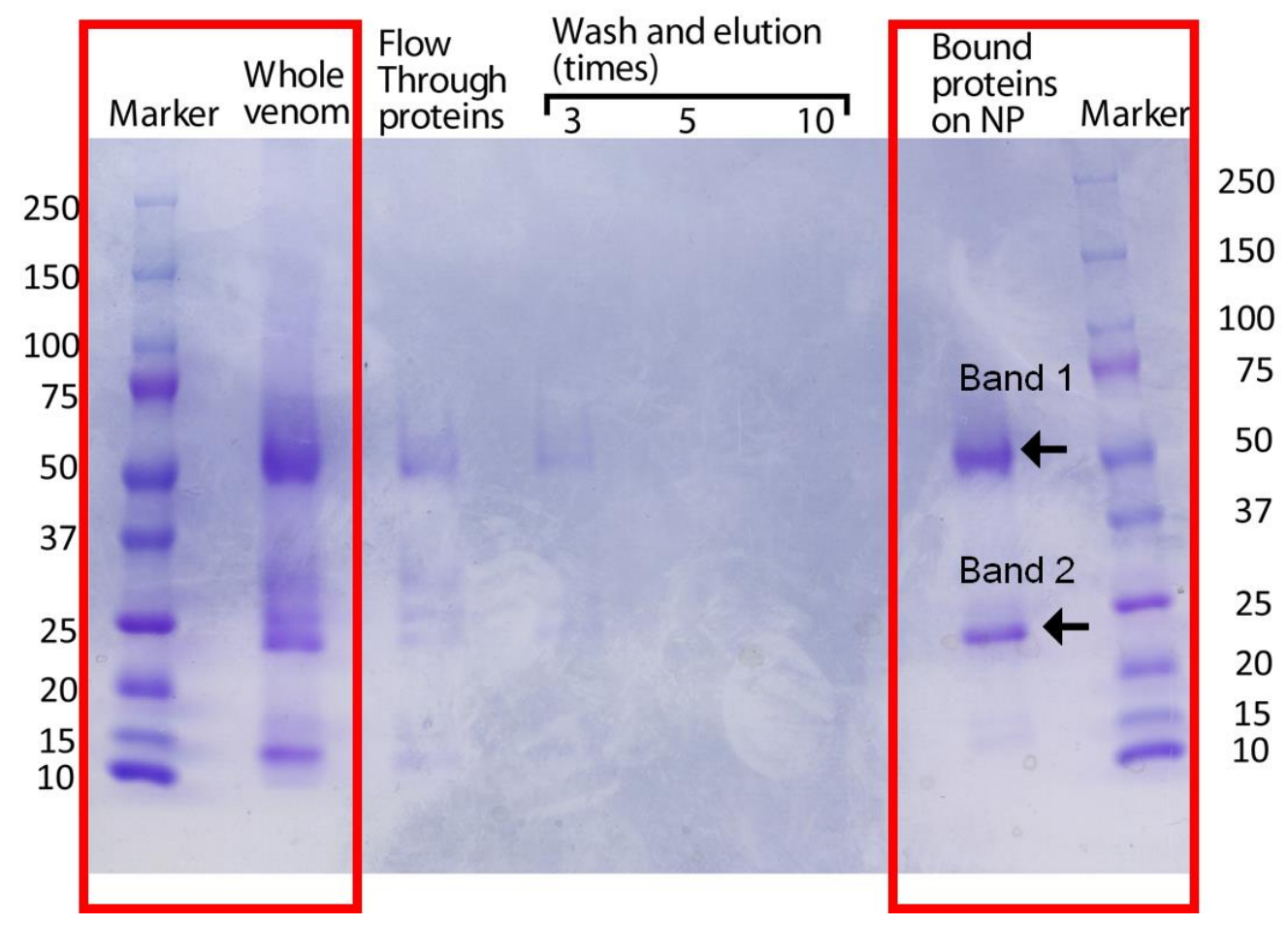

Figure S7. SDS-PAGE visualization of bound proteins on NP16. Red framed lanes are shown in the main text.

(a)

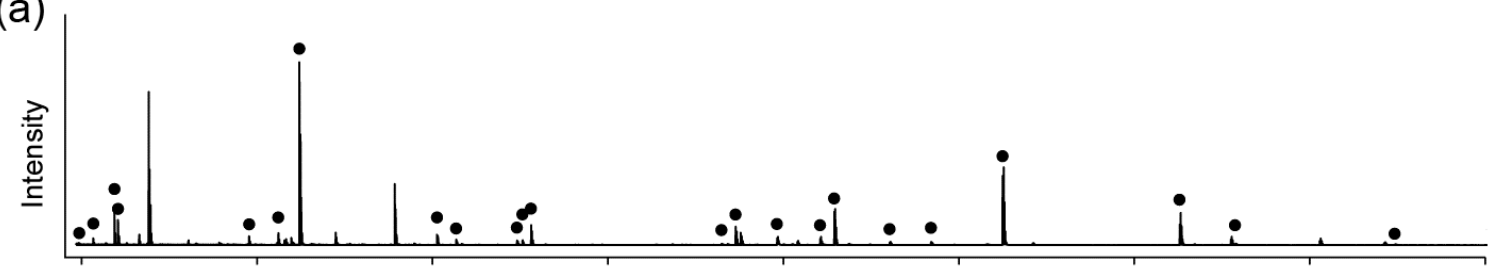

(b)

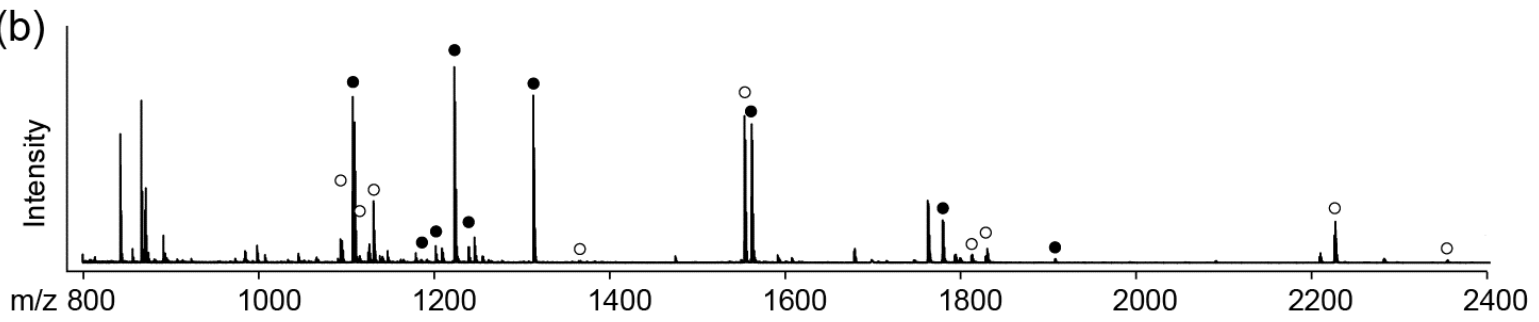

Figure S8. MASS spectrum of proteins in gel band (a) 1 and (b) 2. Matched peptides from VAP2B (black circles in (a)), atroxase (black circles in (b)) and Ht-e (white circles in (b)) are shown as typical results. 
Table S3. Proteins found by MASCOT sequence query and homology search.

\begin{tabular}{ccccccccc}
\hline Band & Protein name & $\begin{array}{c}\text { Accession } \\
\text { number }\end{array}$ & Class & $\begin{array}{c}\text { Mw } \\
\text { (Da) }\end{array}$ & $\begin{array}{c}\text { Cal. } \\
\text { pl }\end{array}$ & $\begin{array}{c}\text { Matched } \\
\text { peptide }\end{array}$ & $\begin{array}{c}\text { Coverage } \\
\text { (\%) }\end{array}$ & $\begin{array}{c}\text { MASCOT } \\
\text { score }\end{array}$ \\
\hline 1 & $\begin{array}{c}\text { Zinc metalloproteinase } \\
\text { disintegrin-like VAP2B }\end{array}$ & Q90282 & PIII & 68203 & 5.03 & 23 & 33 & 120 \\
$(p<0.05)$
\end{tabular}

(a) Searched by homology search using BLAST database.

References

(S1) Beyazit, S.; Ambrosini, S.; Marchyk, N.; Palo, E.; Kale, V.; Soukka, T.; Tse Sum Bui, B.; Haupt, K. Versatile Synthetic Strategy for Coating Upconverting Nanoparticles with Polymer Shells through Localized Photopolymerization by Using the Particles as Internal Light Sources. Angew. Chem. Int. Ed. 2014, 53, $8919-8923$. 